\title{
Pengendalian Internal terhadap Penerimaan Negara Bukan Pajak (PNBP) melalui Penerapan Peraturan Pemerintah Republik Indonesia Nomor 46 Tahun 2002 pada Kantor Wilayah Badan Pertanahan Nasional (BPN) Sumatera Utara
}

\author{
Khairunnida \\ Universitas Amir Hamzah \\ khairunnidamsi@gmail.com
}

\author{
Nova Yessyca Naipospos \\ Politeknik LP3I Medan \\ novayesyca@gmail.com
}

\begin{abstract}
Abstrak
Pembahasan tentang pengaruh partisipasi anggaran dengan senjangan anggaran masih menunjukkan ketidakkonsistenan sehingga hasil yang diperoleh bertentangan. Perbedaan hasil penelitian dapat diselesaikan melalui pendekatan kontijensi dengan menggunakan variabel moderasi. Penelitian ini bertujuan untuk membuktikan pengaruh komitmen organisasi sebagai variabel moderasi terhadap hubungan antara partisipasi anggaran dengan senjangan anggaran.Objek penelitian adalah manajer dan staff yang terlibat dalam proses penyusunan anggaran (40 responden)Periode 2016 . Data dikumpulkan dengan menggunakan kuesioner, enam item untuk partisipasi anggaran sebagai variabel bebas, enam item untuk senjangan anggaran sebagai variabel terikat, dan sembilan item untuk komitmen organisasi sebagai variabel moderasi. Model analisis yang digunakan adalah regresi linear sederhana untuk hipotesis pertama dan analisis regresi moderat untuk hipotesis kedua.Penelitian ini menghasilkan dua penemuan sebagaimana yang diajukan dalam hipotesis penelitian. Pertama, partisipasi anggaran berpengaruh terhadap senjangan anggaran. Kedua, komitmen organisasi tidak mempunyai pengaruh terhadap hubungan antara partisipasi anggaran dengan senjangan anggaran.
\end{abstract}

\section{Kata kunci : Partisipasi Anggaran, Senjangan Anggaran, Komitmen Organisasi}

\section{I.PENDAHULUAN}

\subsection{Latar Belakang}

Kondisi kehidupan bisnis yang semakin kompetitif memberikan dorongan yang sangat besar bagi perusahaan untuk meningkatkan kualitas dan performance nya serta senantiasa mempertahankan kontinyuitas perusahaan. Untuk mencapai tujuannya diperlukan pelaksanaan fungsi-fungsi manajemen yang baik. Fungsi-fungsi tersebut diantaranya adalah perencanaan dan pengendalian.Perencanaan merupakan tindakan yang dibuat berdasarkan fakta dan asumsi mengenai gambaran kegiatan yang dilakukan pada waktu yang akan datang dalam mencapai tujuan yang diinginkan (Nafarin, 2004:5) 
sedangkan pengendalian meliputi langkah-langkah yang dilakukan oleh manajemen untuk memperbesar kemungkinan pencapaian sasaran yang telah ditetapkan dalam perencanaan, dan juga memastikan bahwa seluruh bagian organisasi berfungsi sesuai tujuan. Perencanaan melihat ke masa depan, yaitu menentukan tindakan-tindakan apa yang harus dilakukan untuk merealisasikan tujuan tertentu sedangkan pengendalian melihat ke belakang, yaitu menilai apa yang telah dihasilkan dan membandingkannya dengan rencana yang telah disusun (Hansen dan Mowen, 2004:354).

\subsection{Rumusan Masalah}

Berdasarkan uraian latar belakang masalah di atas, penulis merumuskan masalah yang di teliti sebagai berikut :

1. apakah partisipasi anggaran berpengaruh terhadap senjangan anggaran?

2. apakah komitmen organisasi berpengaruh dalam memoderasi hubungan antara partisipasi anggaran dengan senjangan anggaran?

\subsection{Tujuan Penelitian}

Tujuan dari penelitian ini adalah untuk :

1. membuktikan pengaruh partisipasi anggaran terhadap senjangan anggaran

2. membuktikan apakah komitmen organisasi dapat memoderasi hubungan antara partisipasi anggaran dengan senjangan anggaran.

\section{II.TINJAUAN PUSTAKA}

Hansen dan Mowen (2007:4) mendefinisikan "Anggaran adalah rencana terperinci tentang pemerolehan dan penggunaan sumber daya keuangan dan sumber daya lainnya selama suatu periode waktu tertentu". Anggaran memiliki dua peranan di dalam sebuah organisasi. Anggaran dapat berperan sebagai alat perencanaan dan di sisi lain dapat berperan sebagai alat pengendalian.Penyusunan anggaran biasanya dilaksanakan oleh komite anggaran. Di dalam penyusunannya ada dua pendekatan utama yaitu pendekatan dari atas ke bawah (top down approach) dan pendekatan dari bawah ke atas (bottom up approach).

Menurut Robbins (2003 dalam Wihasfina, 2008) "Partisipasi merupakan suatu konsep di mana bawahan ikut terlibat dalam pengambilan keputusan sampai tingkat tertentu bersama atasannya" sementara Brownell (1982) menyatakan "Partisipasi anggaran sebagai suatu proses dalam organisasi yang melibatkan para manajer dalam penentuan tujuan anggaran yang menjadi tanggung jawabnya". Sord dan Welsch (1995 dalam Falikhatun, 2007) mengemukakan "Tingkat partisipasi yang lebih tinggi akan menghasilkan moral yang lebih baik dan inisiatif yang lebih tinggi pula serta dapat mengurangi tekanan dan kegelisahan para bawahan, karena mereka dapat mengetahui suatu tujuan yang relevan, dapat diterima dan dapat dicapai".

Menurut Anthony dan Govindarajan (2003) "Teori agensi menjelaskan fenomena yang terjadi apabila atasan mendelegasikan wewenangnya kepada bawahan untuk melakukan suatu tugas atau otoritas untuk membuat keputusan". Rahayu (1997) seperti yang dikutip oleh Darlis (2002) menyatakan bahwa partisipasi bawahan akan meningkatkan kebersamaan, menumbuhkan rasa memiliki, inisiatif untuk menyumbangkan ide, dan keputusan yang dihasilkan dapat diterima. Selain itu partisipasi juga dapat mengurangi konflik potensial antara tujuan individu dengan tujuan organisasi sehingga kinerja perusahaan akan meningkat.

\subsection{Kerangka Konseptual penelitian}

Pendekatan dalam penyusunan anggaran secara partisipasi (participative budgeting), memungkinkan para manajer tingkat bawah terlibat dalam pembuatan anggaran. Partisipasi anggaran mengkomunikasikan rasa bertanggung jawab pada para manajer tingkat bawah dan mendorong 
kreativitas, namun pendekatan ini memiliki masalah potensial yaitu memberikan kesempatan bagi manajer dalam membuat kelonggaran dalam anggaran.Diharapkan komitmen organisasi dapat memoderasi hubungan antara partisipasi anggaran dengan senjangan anggaran karena dengan komitmen organisasi yang tinggi, diyakini para manajer akan berusaha memberikan kontribusi terbaik mereka agar tujuan manajer sejalan dengan tujuan organisasional perusahaan. Kerangka konseptual yang digunakan adalah sebagai berikut :

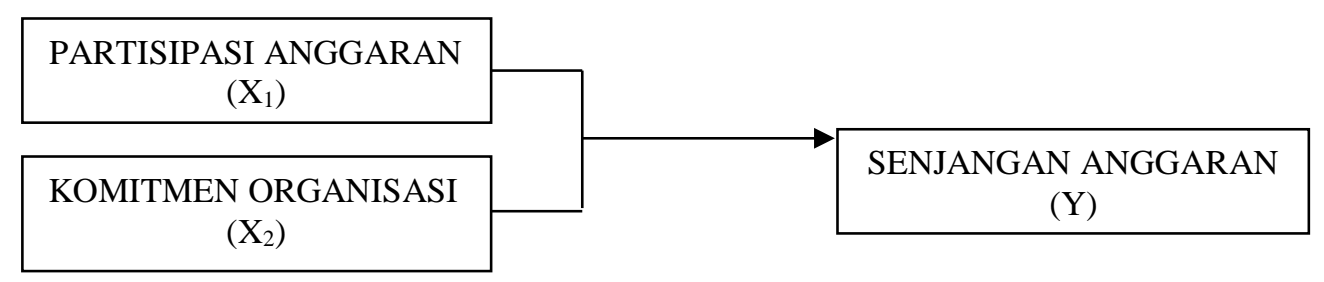

Gambart 2.1.Kerangka Konseptual

\section{METODE PENELITIAN}

\subsection{Jenis dan Sumber Data Penelitian}

Jenis penelitian yang dilakukan adalah penelitian assosiatif yang bertujuan untuk mengetahui hubungan antara dua variabel atau lebih (Sugiyono, 2006:11) dengan bentuk hubungan kausal. Penelitian ini bertujuan untuk mengetahui apakah terdapat pengaruh partisipasi anggaran dan komitmen organisasi terhadap senjangan anggaran. Dalam penelitian ini partisipasi anggaran merupakan variabel independen, komitmen organisasi sebagai variabel moderating, dan senjangan anggaran sebagai variabel dependen. Dimensi waktu penelitian adalah cross sectional yaitu studi lintas seksi dilaksanakan satu kali dan mencerminkan potret dari suatu keadaan pada satu saat tertentu (Erlina dan Sri Mulyani, 2007:70).

\subsection{Populasi dan Sampel Penelitian}

Populasi adalah wilayah generalisasi yang terdiri atas objek/subjek yang memiliki kualitas dan karakteristik tertentu yang ditetapkan oleh peneliti untuk dipelajari dan kemudian ditarik kesimpulannya (Sugiyono, 2006:72). Populasi dalam penelitian ini adalah seluruh manajer dan tim penyusun lain yang terlibat dalam penyusunan anggaran di PT Central Proteinaprima Tbk Periode dengan rincian di bawah ini.Manajer,11 orang Supervisor,15 orang Staff lainnya,14 orang.Jumlah populasi dalam penelitian berjumlah 40 orang Tahun 2016. Seluruh populasi tersebut akan dijadikan sampel. Oleh karenanya sampel yang diambil dari populasi harus betul-betul representatif. Unit analisis yang digunakan dalam penelitian ini adalah tingkat individu, karena mengamati perilaku manajer dan staff anggaran lain.

\section{HASIL PENELITIAN}

Bab ini akan menyajikan pembahasan hasil-hasil pengujian yang dilakukan, yang terdiri dari statistik deskriptif, uji kualitas data, uji asumsi klasik dan uji hipotesis dengan analisis regresi sederhana dan regresi linear berganda yang menggunakan variabel moderasi.

\section{A. Statistik Deskriptif}




\begin{tabular}{|c|c|c|c|c|c|}
\hline \multicolumn{6}{|c|}{ Tabel } \\
\hline \multirow[b]{2}{*}{ Model } & \multicolumn{2}{|c|}{ Unstandardized Coefficients } & $\begin{array}{l}\text { Standardized } \\
\text { Coefficients }\end{array}$ & \multirow[b]{2}{*}{$\mathrm{t}$} & \multirow[b]{2}{*}{ Sig. } \\
\hline & $B$ & Std. Error & Beta & & \\
\hline $1 \quad$ (Constant) & 14.750 & 6.469 & & 2.280 & .029 \\
\hline $\mathrm{X} 1$ & .003 & .314 & .005 & .011 & .991 \\
\hline X2 & -.592 & .488 & -.453 & -1.212 & 234 \\
\hline$X 1{ }^{*} X 2$ & .039 & .024 & .883 & 1.607 & .117 \\
\hline
\end{tabular}

a. Dependent Variable: $Y 1$

Sumber : Hasil pengolahan data dengan program statistik, 2016 (data diolah)

Berdasarkan tabel di atas dapat dibuat persamaan :Y = 14,750 + 0,003 X1 - 0,592 X2 + 0,039X1*X2. Dari ketiga variabel independen yang dimasukkan dalam persamaan regresi, tidak satupun variabel menunjukkan pengaruh yang signifikan. Variabel partisipasi anggaran memberikan nilai koefisien 0,003 dengan tingkat signifikansi 0,991 >0,05, variabel komitmen organisasi memberikan nilai koefisien -0,592 dengan tingkat signifikansi 0,234>0,05, dan variabel moderating yang merupakan interaksi partisipasi anggaran dengan komitmen organisasi memberikan koefisien 0,039 dengan tingkat signifikansi 0,117. Dari uraian di atas dapat disimpulkan bahwa variabel komitmen organisasi bukanlah merupakan variable moderasi sehingga hipotesis kedua yang menyatakan komitmen organisasi berpengaruh terhadap hubungan antara partisipasi anggaran dengan senjangan anggaran, ditolak.

\subsection{Pengaruh Partisipasi Anggaran terhadap Senjangan Anggaran}

Berdasarkan hasil pengolahan data yang terlihat pada tabel di atas, juga diperoleh hasil uji t yang diperlukan untuk menguji signifikansi konstanta dan variabel independen. Pada kolom signifikan, konstanta dan variabel independen (partisipasi anggaran) mempunyai angka signifikan jauh dibawah 0,05 ( 0,000 untuk konstanta partisipasi dan 0,000 untuk konstanta senjangan anggaran). Hal ini menunjukkan bahwa partisipasi anggaran berpengaruh positif terhadap senjangan anggaran..

\subsection{Pengaruh Komitmen Organisasi Terhadap Senjangan Anggaran}

Hasil Penelitian menunjukkan bahwa variabel komitmen organisasi bukanlah merupakan variabel moderasi sehingga hipotesis kedua yang menyatakan komitmen organisasi berpengaruh terhadap hubungan antara partisipasi anggaran dengan senjangan anggaran, ditolak.

\subsection{Kesimpulan}

\section{KESIMPULAN DAN SARAN}

Berdasarkan hasil analisis pada bab IV diperoleh kesimpulan yang akan diuraikan dibawah ini.

1. Hipotesis pertama menunjukkan bahwa partisipasi dalam penyusunan anggaran berpengaruh terhadap senjangan anggaran. Dapat disimpulkan juga bahwa pengaruh partisipasi anggaran terhadap senjangan anggaran menunjukkan pengaruh positif yang berarti semakin tinggi partisipasi, maka akan semakin tinggi pula senjangan anggaran.

2. Dari hasil analisis hipotesis pertama diperoleh nilai adjusted $\mathrm{R}$ square $=0,505$. Angka ini menunjukkan bahwa kemampuan variabel partisipasi anggaran dalam menjelaskan atau memberikan sebagian besar informasi yang dibutuhkan untuk memprediksi variabel senjangan anggaran yang dapat dijelaskan oleh persamaan regresi adalah sebesar 50,5\%, sedangkan sisanya yaitu $49,5 \%$ dijelaskan oleh variabel lain di luar persamaan model. 
3. Hipotesis kedua menunjukkan bahwa komitmen organisasi tidak berpengaruh dalam memoderasi hubungan antara partisipasi anggaran dengan senjangan anggaran. Hal ini dibuktikan dengan melakukan analisis regresi moderasi dengan uji selisih mutlak yang merupakan interaksi antara partisipasi anggaran dengan komitmen organisasi yang diukur dengan nilai absolut. Hasil analisis hipotesis kedua menunjukkan bahwa secara simultan variabel partisipasi anggaran, komitmen organisasi, serta interaksi partisipasi dengan komitmen organisasi berpengaruh terhadap senjangan anggaran. Namun secara parsial hanya variabel partisipasi anggaran yang mempunyai pengaruh signifikan terhadap senjangan anggaran. Hal ini dapat dilihat dari nilai koefisien dan tingkat signifikansi setiap variabel yang diteliti.

\subsection{Saran}

Terlepas dari beberapa keterbatasan yang dimiliki, penelitian ini diharapkan dapat bermanfaat sebagai bahan masukan dan justifikasi bagi kepentingan praktis, dalam rangka penggunaan dan pengembangan sistem penyusunan anggaran. Berikut beberapa saran berkaitan dengan keterbatasan penelitian.

1. Budgetary slack harus dikontrol untuk dapat meningkatkan efektivitas anggaran.

2. Untuk mendapatkan hasil yang optimal dalam penelitian, maka sebaiknya diusahakan menggunakan metode observasi atau pengamatan langsung kepada objek atau metode eksperimen sebagai pengganti metode kuesioner.

3. Memperluas lingkup atau wilayah penelitian, memperbanyak sampel dan pemilihan sampel yang acak, sehingga hasil penelitian dapat digeneralisasikan dan dapat memberikan kontribusi dalam pengkajian aspek-aspek keperilakuan dalam pengembangan teori-teori akuntansi manajemen.

4. Berdasarkan hasil dan keterbatasan penelitian, perlu dilakukan penelitian berkelanjutan dengan menggunakan berbagai faktor kontekstual yang dapat dipertimbangkan sebagai variabel moderating karena diduga berpengaruh dalam partisipasi dan senjangan anggaran seperti reward, budget emphasis, ketidakpastian strategik, gaya kepemimpinan, ketidakpastian lingkungan, kinerja manajerial, interaksi asimetri informasi, group cohesiveness dan budaya perusahaan.

\section{DAFTAR PUSTAKA}

Anthony, R.N. dan Govindarajan, 2003. Sistem Pengendalian Manajemen, Buku 2 Edisi 1, Salemba Empat, Jakarta.

Asriningati, 2006. "Pengaruh Komitmen Organisasi dan Ketidakpastian Lingkungan Terhadap Hubungan Antara Partisipasi Anggaran Dengan Senjangan Anggaran Studi Kasus Pada Perguruan Tinggi Swasta di Daerah Istimewa Yogyakarta”, Skripsi, Departemen Akuntansi Fakultas Ekonomi, Universitas Islam Indonesia, Yogyakarta.

Baiman, S., dan J. H. Evans III, 1983. "Pre-Decision Information and Particpative Management Control System”, Journal of Accounting Research 21, 371-395.

Brownell, P., 1982. "Participation in Budgeting Process : When It Works and When It Doesn't", Journal of Accounting Review ,Vol.1, 124-153.

Camman, C., 1976. "Effects of The Use of Control System", Accounting, Organizations, and Society, Vol.4, 301-313.

Cook, J.D. dan T.D.Wall, 1980. "New York Attitudes Measures of Trust, Organizations Commitment, and Personal Need Nonfullfillment". Journal of Accupational Psychology, 39-52. 
Darlis, E., 2002. “Analisis Pengaruh Komitmen Organisasional dan Ketidakpastian Lingkungan terhadap Hubungan Antara Partisipasi Anggaran dengan Senjangan Anggaran", Jurnal Riset dan Akuntansi Indonesia, Vol.5 No.1.

Dunk,A.S., 1993. "The Effect of Budget Emphasis and Information Assymetry on The Relation Between Budgetary Participation and Slack". The Accounting Review 68, April, 400-410.

Erlina dan Srimulyani, 2007. Metodologi Penelitian Bisnis untuk Akuntansi dan Manajemen, USU Press, Medan.

Falikhatun, 2007. "Interaksi Informasi Asimetri, Budaya Organisasi, Group Cohesiveness dalam Hubungan Antara Partisipasi Penganggaran dan Budgetary Slack", Simposium Nasional Akuntansi X, Makassar.

Garrison dan Noreen, 2007. Managerial Accounting Buku 2 Edisi 11, Salemba Empat, Jakarta.

Ghozali, Imam, 2002. Aplikasi Analisis Multivariate dengan Program SPSS, BP Undip, Semarang.

Govindarajan , V., 1986. "Impact of Participation in The Budgeting Process on Managerial Attitudes and Perfomance : Universalistic and Contingency Perspective”, Decision Science 17, 496-516.

Hansen dan Mowen, 2004. Management Accounting Buku 1 Edisi 7, Salemba Empat, Jakarta.

Ikhsan, Arfan dan La Ane, 2007. "Pengaruh Partisipasi Anggaran terhadap Senjangan Anggaran dengan Menggunakan Lima Variabel Pemoderasi", Simposium Nasional Akuntansi X, Makassar.

Jurusan Akuntansi Fakultas Ekonomi Universitas Sumatera Utara, 2004. Buku Petunjuk Teknis Penulisan Proposal Penelitian dan Penulisan Skripsi, Medan.

Lowe, E.A. dan R.W.Shaw,1968. “An Analysis of Managerial Biasing : Evidence from a Company’s Budgeting Process", The Journal of Management Studies 5, Oktober 304-315.

Lukka, K. 1988. "Budgetary Biasing in Organizations Theoritical Framework and Empirical Evidence", Accounting, Organizations, and Society 13, 281-301.

Luthans, F., 1998. Organizational Behaviour, $8^{\text {th }}$ Edition, Boston : McGraw-Hill,Inc.

Merchant, K.A. 1985. "Budgeting and Propersity to Create Budgetary Slack", Accounting, Organizations, and Society10, 201-210.

Milani. 1975. "The Relationship of Participation in Budget Setting to Industrial Supervisor Perfomance and Attitudes : A Field Study", The Accounting Review, April, 274-284.

Minan, Kersna, 2005. "Pengaruh Komitmen Organisasi terhadap Hubungan Antara Partisipasi Anggaran dengan Senjangan Anggaran pada Perguruan Tinggi Swasta di Kota Medan", Tesis, Magister Akuntansi Program Pascasarjana, Universitas Sumatera Utara, Medan.

Mulyadi dan Setyawan, 2001. Sistem Perencanan dan Pengendalian Manajemen, Salemba Empat, Jakarta 
Nafarin, M., 2004. Penganggaran Perusahaan Edisi Revisi, Salemba Empat, Jakarta.

Nouri, H., dan R.J.Parker, 1996. "The Effects of Organizational Commitment on Relation Between Budgetary Participation and Budgetary Slack", Behavioural Research in Accounting, Vol. 8, 74-90.

Onsi, M., 1973. "Factor Analysis of Behavioural Variables Affecting Budgetary Slack", The Accounting Review, July, 535-548.

Patria, Belianus, 2005. "Pengaruh Partisipasi Anggaran terhadap Senjangan Anggaran dengan Komitmen Organisasi sebagai Variabel Moderating, Studi Empiris pada Kawasan Industri Maluku", Jurnal akuntansi dan Keuangan, Vol.7 No.2, 117-130.

Porter, L.W., et al., 1974. "Organizational Commitment, Job Satisfaction, and Turn Over Among Psyatric Technician”, Journal of Applied Phsycology, 603-609.

Schiff, M., and A.W.Lewin, 1970. "The Impact of People on Budgets", The Accounting Review, Vol.45, 259-268.

Sugiyono, 2006. Metode Penelitian Bisnis, Penerbit Alfabeta, Bandung.

Wihasfina, Frisilia, 2008. "Pengaruh Partisipasi Anggaran terhadap Kinerja Manajerial pada PT Cakra Compact Aluminium Industries", Skripsi, Departemen Akuntansi Fakultas Ekonomi, Universitas Sumatera Utara, Medan.

Young, S.M., 1985. "Participative Budgeting : The Effects of Risk Aversion and Assymetric Informations of Budgetary Slack", Journal of Accounting Research 23, 829-842. 